\title{
Exclusion and contests over wetlands used for farming in Zimbabwe: a case study of broad-ridge and broad-furrow tillage system on Zungwi Vlei
}

\author{
Alexio Mbereko ${ }^{1}$ \\ Billy B. Mukamuri \\ Moses J. Chimbari
}

\begin{abstract}
In Zimbabwe, a broad-ridge and broad-furrow tillage system was promoted by the state, scientists and a nongovernmental organisation for its presumed agronomic and environmental viability and economic returns for small farmers. Zungwi vlei, a wetland of value to the community was transformed from a common use natural resource into a limited access broad-ridge and broad-furrow irrigation landscape that benefited a small number of people. Our study sought to understand conflicts over natural resources access, use and management arising from this land use change. The study adopted mixed methods combining qualitative and quantitative data collection tools. The results indicated the presence of a wide range of internal and external conflicts following the transformation of the landscape. Prior to the transformation, low levels of conflict were noted. We concluded that despite the ability of the broad-ridge and furrow tillage system to boost agricultural productivity per square meter, it triggered considerable resource use conflicts as fewer families directly benefited from the innovation.
\end{abstract}

Key words: Development, vlei, agricultural technology, resources conflict, political ecology, Zimbabwe

\begin{abstract}
Au Zimbabwe, un système de buttage et sillonage a été promu par l'Etat, les scientifiques et une organisation non gouvernementale pour sa viabilité agronomique et environnementale et un augmentation des rendements économiques pour les petits agriculteurs. Zungwi vlei, une zone humide de valeur pour la communauté, a été transformé à partir d'une ressource naturelle de l'usage commun dans un accès limité à un système d'irrigation, qui a bénéficié d'un petit nombre de personnes. Cette étude a essayé de comprendre les conflits sur l'accès des ressources naturelles, l'utilisation et la gestion découlant de ce changement d'utilisation des terres. L'étude a adopté des méthodes mixtes, combinant des données qualitatives et quantitatives. Il y avait un large éventail de conflits internes et externes suivants la transformation du paysage. Avant la transformation, les faibles niveaux de conflit ont été notées. Nous avons conclu que, malgré la capacité de la le système de sillonage et buttage stimuler la productivité agricole par mètre carré, ce qui a déclenché des conflits considérables par rapport à l'utilisation des ressources parce que moins de familles ont bénéficié directement de l'innovation.
\end{abstract}

Mots clés: développement, vlei, technologies agricoles, les conflits de ressources, l'écologie politique, Zimbabwe

\section{Resumen}

En Zimbabwe, un sistema de cultivación empleando surcos anchos fue promovido entre pequeños productores por parte del estado, científicos y una organización no-gubernamental, quienes basaron su decisión en su supuesto viabilidad ambiental y rentabilidad agronómica. Zungwi vlei, un humedal de uso comunal fue convertido de un recurso natural de acceso libre a un paisaje de agricultura de riego que beneficiaba a un pequeño grupo. Nuestro estudio buscaba entender los conflictos sobre acceso, uso y manejo de recursos naturales que surgió de este cambio en el uso de suelo. Utilizamos métodos cualitativos y cuantitativos para la recolección de datos. Los resultados de la investigación indican la presencia de

\footnotetext{
${ }^{1}$ Dr. Alexio Mbereko and Prof. Moses J. Chimbari, College of Health Sciences, University of KwaZulu-Natal, Howard College, Durban 4041, South Africa. Email: ambereko "at" yahoo.co.uk, chimbari "at" ukzn.ac.za. Dr. Billy. B. Mukamuri, Centre for Applied Social Sciences, University of Zimbabwe, P.O Box MP167, Mount Pleasant, Harare, Zimbabwe. Email: bmukamuri "at" sociol.uz.ac.zw. We would like to acknowledge financial support from ICRAF (ANAFE grant), SIMA/IDRC and WARFSA (P245). Special thanks go to the Zimbabwe SIMA/IDRC team, University Lake Kariba Research Station and the Centre for Applied Social Sciences (University of Zimbabwe) staff for their support. Thankyou to two referees for comments and Simon Batterbury for editing.
} 
conflictos internos y externos a la comunidad, que resultaron del cambio al paisaje. Se detectó bajos niveles de conflicto antes de la transformación. No obstante el aumento de productividad por metro cuadrado efectuado por el nuevo sistema de cultivo de surcos anchos, el cambio al paisaje detonó un nivel considerable de conflictos sobre recursos porque porque pocas familias gozaron de los beneficios de la innovación.

Palabras clave: Desarrollo, vlei, tecnología agrícola, conflicto sobre recursos, ecología política, Zimbabwe

\section{Introduction}

Vleis, a term derived from Afrikaans, are valley bottoms or depressions that form natural drainage systems with or without a developed and distinct stream (Mharapara 1995). Vleis have received several definitions over time (Matiza 1992; Mharapara 1995; Rattray et al. 1953; Whitlow 1990). They are a type of wetland that is saturated for most of the year, can experience seasonal overland flow, and water can be absorbed release later, like a sponge. Vleis are fragile ecosystems that are easily degraded and difficult to restore. In the 1990s the Zimbabwean Research and Specialist Services, a department of the Ministry of Agriculture, experimented with a broad-ridge and broad-furrow tillage system as a possible scientific method for sustainable vlei cultivation. This tillage system was aimed at conserving fragile vlei soils while returning soil moisture, and promoting agricultural production for the market. The tillage system was implemented on a trial basis in five areas in Zimbabwe. Such innovations were in line with the global drive to develop irrigation systems in drylands to ensure sustainable agricultural development.

This article analyzes the outcomes of implementing the broad-ridge and broad-furrow system in Mazvihwa-Zimbabwe, which at the same time converted a common property vlei to private property. We apply a political ecology framework combining ecological and political economy to interpret the contestations over the Zungwi vlei in Zvishavane.

A classical political ecology approach in this context traces development programme outcomes from governments, research centres and non-governmental organisations (NGOs) rather than simply blaming proximate conditions and local forces for any failures of development, or any negative environmental outcomes. In the case analysed, the government supported pro-agricultural development but the local water rights regime in the Zungwi vlei was marginalised in the process. Thus, the study sought to answer the question, how does a technical agricultural intervention change local power relations and access to vlei resources?

\section{The context}

\section{The policy background}

In Zimbabwe, agriculture and environmental management are considered important economic drivers, and the government takes a central role in policy formulation and governance in those sectors. Although the government tries to align with international norms of policy formulation, elite interests influence the process significantly (Addison and Laakson 2003). A top-down policy approach ignores the fact that villagers are active social actors with their own interests. The traditional structures characterised by chiefs, headmen and kraal heads only implement programmes on the ground, and they are not fully engaged in policy formulation.

Government policy on agriculture has depended on the national fiscal policies of the day. In the first decade after independence in 1980, the government adopted a dominantly populist approach informed by the socialist ideals that had informed the struggle for independence (Mbereko et al. in press). In 1989, the International Monetary Fund and World Bank obligated the Zimbabwean government to adopt neo-liberal policies, rolled out in the 1990s to secure international aid (Bhalla et al. 1999). The Economic Structural Adjustment Programme (ESAP) shifted the policy focus towards privatisation and capital accumulation in all sectors. After 2000, the government policy 'juggled' between the left (populist, authoritarian), and the right (neo-liberal and with a parliamentary democracy) (Bhalla et al. 1999; Moore 1991).

Investment and agricultural policies mirror the same stages of political and economic history. In the 1980s, agricultural policy prioritised land redistribution and rural infrastructure development (Moyo 2001). But agricultural mechanisation and systems were soon seen as strategies to ensure food security and to 
produce for the market (Mtapuri 2008). From 1990 to1997, the government prioritised farm mechanisation. In the post-1998 era, ZANU PF was under stiff competition from opposition political parties, and the largescale withdrawal of foreign aid. Partisan distribution of agricultural resources and cheaper agricultural technologies were promoted in order to gain political support. The private sector, donors working through NGOs, and government institutions promoted research on agricultural technologies and systems that could be accessible and managed by rural peasant farmers to improve the agricultural sector (Bolding 2004; Mharapara 1995). A contradiction remains, in that macro level development discourses implicitly assume a priority for market led economic growth and in addition, the need to have new 'clean' energy supplies to support the national economy. By contrast local discourses place a value on household or community reproduction and employ a diverse and plural set of values (Ariza et al. 2010).

It was in 1998, entering the phase of economic austerity and environmental hardship, that the Zungwi vlei was transformed using a broad-ridge and broad-furrow tillage system. The tillage system involves modified vlei terrain with alternating contour ridges and furrows to support crops with different water requirements. At this time the government was promoting agriculture in the communal areas in order to abate food insecurity resulting from the failure of the Economic Structural Programme. Zimbabwe was experiencing prolonged droughts against a backdrop of the withdrawal of international aid and a declining economy. At that time and across many parts of the country, vleis offered an opportunity to enhance food security and household livelihoods. The article argues that unequal power relations informed the development of the broad-ridge and broad-furrow tillage system, paying minimum attention to the water rights contests over vleis in the Mazvihwa area, that had already been highlighted by scholars including Scoones and Cousins (1989, 1994).

\section{Conceptual framework: political ecology's interpretation of innovation and rural development}

The relationship is contested between the state and capital on one hand and the environment and poor societies on the other (MacKendrick and Davidson 2007). Some scholars argue for ecological modernisation, which assumes that government can work with capital and non-governmental organisations (NGOs) to achieve environmental friendly development (MacKendrick and Davidson 2007). On the other hand, critical scholarship informed by Marxist analysis (ecological Marxism and political ecology) assume that because of the inherent contradictions in in a capitalist system, the pursuit of commercial benefit will degrade the environment, and do so unequally - as in the marginalised poor societies of Africa (Ciccantell 2001; Harvey 2003; O'Connor 1998).

The interaction of the state, capital and NGOs under neo-liberalism can result in privatisation and capital accumulation by powerful groups and institutions. Harvey (2003) referred to this modern accumulation as "accumulation by dispossession." One form of accumulation by dispossession is when the state releases assets that the international or local capitalist class then appropriates for commercial purposes (Harvey 2003). The concept can be expanded to understand not only the effects of material accumulation by capitalists, but to include more powerful community members taking control of common property (in this case of wetlands), and doing so when structural support is offered to that community. The political discourse at the global and national scale characterised by the interactions of the state, capital and NGOs, inform the interactions between society and the natural environment on the ground (Frank 2007; Hoffman 2001).

It was these interactions that we studied on the Zungwi vlei: state driven dispossession of one group of users. This is driven by decreasing soil fertility and biodiversity loss: and by poverty, social inequality, and the actions of the state and the market. More precise understanding of the political ecology of wetland resource use and abuse is needed (Woodhouse et al. 2000). Literature from southern Africa has demonstrated that in drylands natural resources are limited, and contested by local people (Mbereko et al. 2007; Scoones and Cousins 1994; Sithole 1999). We contend that political ecology provides a useful conceptual framework to understand the contestations over natural resources by social actors. Political ecology research examines power relationships that reinforce inequities in decision-making over resource access at a variety of scales (Clifford 2009; King 2010). Environmental problems are linked to human degradation: poverty, social inequality, injustice or oppression, alienation, illness and human rights violations (Thrupp 1993). 
Development denotes transformation, and embracing a new order (Neumann 2005). The 'tragedy of development' describes people who do not fit in the new order, for example those unwilling or unable to respond to structural pressures to earn foreign currency or to meet a global demand for a product. International organisations, governments and academics with interests in rural development have advocated for the centrality of expert driven technology and knowledge systems to aid community development (Berger 2005; Juma 2001; Kwansah-Aidoo and Obijiofor 2006; Short 2007; Webersik and Wilson 2009). Scientists who limit their analysis of agricultural and environmental problems to natural systems promote the implementation of technological and modern scientific practices as solutions. By contrast, political ecology adopts a multi-scalar and holistic approach by analysing the dialectics of the environmental and social systems. According to Thrupp (1993) in the political ecology perspective, goals of sustainable development emphasise or require social equality and respect of human rights, as well as ecological soundness and economic productivity. Under this framework no technology is neutral or objective. The broad-ridge and broad-furrow technology reflect the world view of the designers and the market structure, and governments and institutions that commercialise it. Political ecologists also criticise the political and economic elites that aid technological innovation by justifying highly unequal patterns of human use of the environment, arguing that the interventions serve 'the greater social good' (Bryant 1998). Yet, in reality these are at the expense of the spatially or culturally contextualised knowledge of local actors. The forced implementation of modern scientific knowledge systems that replace the old practices for common resource management is a failure to appreciate the social actor as an active agent in constructing their reality.

Subordinate individuals and groups are active social agents as they can negotiate or contest the technologies of the powerful elite with the following outcomes; strategically accommodation; resistance; or local adaptation (Peluso 1992; Scott 1990; Soron 2004). A number of examples from Africa demonstrate resistance to good technologies by communities (Abdulai and Huffman 2005; Adesina and Baidu-Forson 1995; Tripp 2001). A classical case is the grassroots actions that led to the failure of the Ujamaa system in Tanzania. In recent times, neoliberal regimes have promoted the increased privatisation of common pool resources to maximise use values (Bakker 2007). The privatisation of water is conceptualised under 'neoliberalizing nature' which argues for the creation of private property rights for resources (Bakker 2007; Heynen and Robbins 2005). Activists, by contrast, protest against privatisation of water resources, arguing that water is a human right (Bakker 2007).

Deregulation by the state leaves user groups to manage land and to determine the most economic use, leading to the enclosure of many vleis. Enclosure allows for the dispossession of everyone by a few individuals to accumulate wealth, thus enhancing their power and resulting in social inequalities (Heynen and Robbins 2005). The rapid privatisation of common pool vleis resources disturbs access to wetland resources that are usually negotiated and contested over a much longer long historical period.

In this case 'access' is the ability to benefit from the vlei resources. This conceptualisation of access brings attention to a wider range of power dynamics that inform social relationships that can exclude or enable people to benefit from them (Ribot and Peluso 2003). According to Ribot and Peluso (2003: 154):

These powers constitute the material, cultural and political-economic strands within the "bundles" and "webs" of powers that configure resource access. Different people and institutions hold and can draw on different "bundles of powers" located and constituted within "webs of powers" made up of these strands.

Hall et al. (2011) analysed the power dynamics that inform exclusion of social actors from land. They defined exclusion as the ways in which people are prevented from benefiting from natural resources such as vleis. Scholars who analyse access in this way go beyond examining property rights to interrogate the politics that condition the ability to benefit or processes of exclusion (Hall et al. 2011; Ribot and Peluso 2003). Exclusion is associated with issues of contention, conflict, and power relations among actors and is closely linked to possession, denoting the control and maintenance of the contested access to natural resources valued for contributions to livelihoods (Hall et al. 2011). The loss of access and usufruct rights to common pool resources results in conflicts over vleis resources (Scoones and Cousins 1994). 
According to Bryant (1998) political ecology also conceptualises conflicts as struggles over meaning, as they are battles over material and non-material issues. It is important to understand the historical socioeconomic context and political power relations which circumscribe contestations over environmental services. Ecology, society and technology affect and constrain sustainable development outcomes but they are set within an agrarian political economy, important for the construction and interpretation of discourses and asserting power over the social actors (Scott 1985).

These different dimensions of exclusion, dispossessions and the assertion of power are now related to the specific contestations over Zungwi vlei. After setting the scene, we present the contestations over the vlei that result from changes in natural resources access, use and management.

\section{Background to the study}

Wetlands have been valued as sources, sinks, and transformers of a multitude of chemical, biological and genetic materials, but less so for achieving human livelihoods, with the exception of fishing (Mitsch and Gosselink 2007). A number of environmental pacts create frontiers between wetlands and people - for example the Ramsar Convention, and the Convention on International Trade in Endangered Species (CITES). At the national level these have led to legal outcomes that preserve wetlands from human impacts. In Zimbabwe, vleis cultivation was prohibited during the colonial period under the Natural Resources Act of 1941 (revised 1951). The Environmental Management Act (2002) continued the ban. It was based on claims of environmental depreciation, but with little scientific monitoring (Mukamuri and Mavedzenge 2000; Wilson 1986). Wilson (1986) argued that the ban was actually intended to make it difficult for Black Africans to compete with Whites in agricultural production. In reality, cultivation of vleis continued (Mharapara 1995).

The trajectory of political and economic events in Section 2 runs parallel to vleis demand and use, expressed as competition for access. During the 1980s vleis, like other wetlands, were thought to promote diseases such as malaria and schistosomiasis (Appleton and Madsen 2012; Balasubramanian et al. 2007; Mitsch and Gosselink 2007). In Zimbabwe, there was little pressure to utilise vleis for agriculture because of relatively higher and reliable rainfall which could support upland farming on soils that are easier to work, and rural households had reasonably good support from the government and NGOs (Magadza 2010; Makadho 1995). The populist government was supported by good economic performance, and it allowed investment in communal agriculture (Moyo 2001).

The winds of fortune turned from 1990. The neo-liberal policies of the 1990s resulted in serious economic problems (Brett 2005; Sachikonya 2002). The economy performed badly, and the government was broke and could no longer support poor rural communities to the same extent (Brett 2005). During two droughts and economic failure over the decade, rural people exploited all available natural resources. Poorer households settled on marginal land, and in the drylands especially, they started to farm the vleis. In Zimbabwe, vleis have historically been used as insurance against drought, since crops thrive in the fertile soils with residual moisture (Mbereko et al. 2007). Thus, in drylands vleis provided the most valuable resources for rural communities' agricultural production (Matiza 1992; Mbereko et al. 2007; Mharapara 1995; Scoones and Cousins 1994; Sithole 1999). Scoones and Cousins (1991) argue this is the root of conflicts over vleis.

Zungwi vlei was a valued natural resource for the surrounding communities in the Mazvihwa area (Figure 1). The benefits derived from it include grazing and watering livestock, sourcing domestic water, fetching grass, gathering wild fruits, cultivation and gardening, and collecting worms for fishing (Mbereko et al. 2007). Also, people from surrounding villages fetched grass for thatching. The vlei and the adjacent mountain have spiritual functions and have value to the traditional leadership. Thus, Zungwi vlei provided numerous resources and benefits to the Mazvihwa people. 


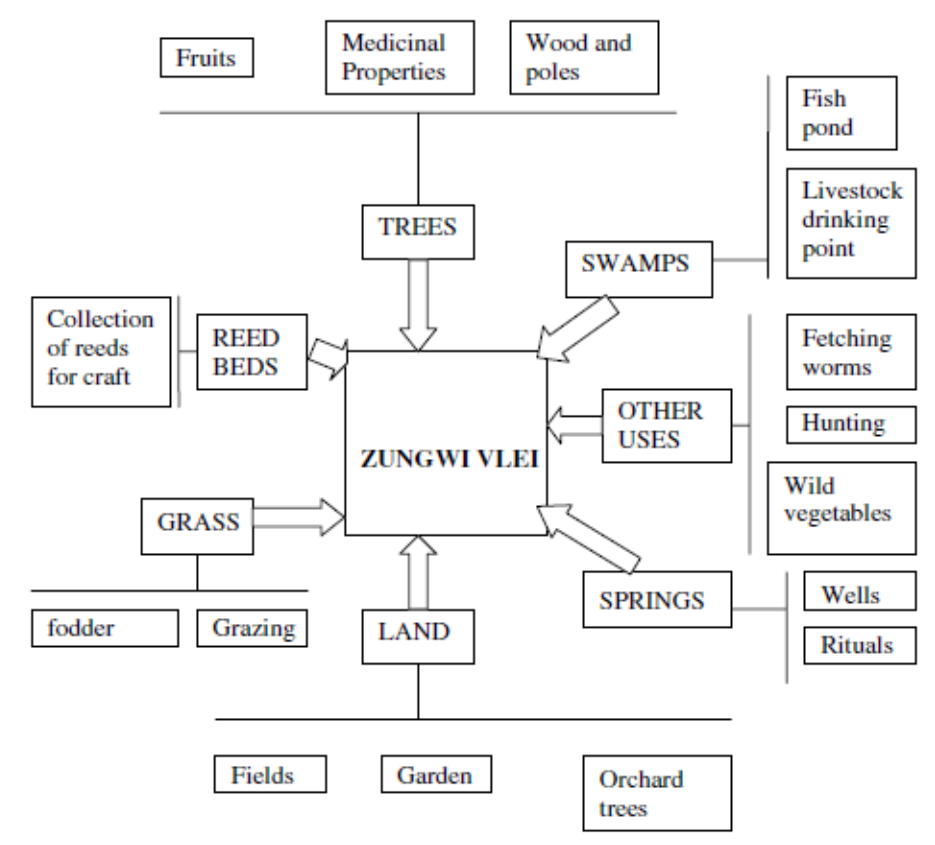

Figure 1: Resource units in Zungwi vlei from which surrounding communities derived benefits. Source: Mbereko et al. (2007:1294).

\section{Broad-ridge and broad-furrow technology}

Broad-ridge and broad-furrow technology generally increases crop yields and conserves the vlei ecosystem (Mharapara 1995). Figure 2 shows a typical system. Furrows and ridges are developed in an alternating sequence starting from highest point. The furrows are designed in such a way that they will hold water to a level of approximately $30 \mathrm{~cm}$ before it reaches capacity and overflows into the furrow below. The water finally drains into a small dam. The furrows and the ridges are about two meters wide. On the ridges plants that do not tolerate waterlogged conditions are grown, for example maize during the rainy season. In summer rice is the man crop in the furrow, because of waterlogging. During the dry season wheat and green mealies (corn) are planted in the furrows.

Zvishavane district is located in the south-central part of Zimbabwe (Figure 3). The area receives rainfall of between $500 \mathrm{~mm}$ and $600 \mathrm{~mm}$ per year. Zungwi vlei has a broad-ridge and broad-furrow system. It is 70 hectares in size and is located in Virimayi village, in headman Musibandi's area. Virimayi village shares a boundary with Sikovo village under headman Mwedzi. The broad-ridge and broad-furrow tillage system now occupies about 45 hectares of the prime part of the vlei. Subsistence farming was dominant in the study area at the time of research, and a significant number of vleis were under cultivation. The major economic activities in the study area were mining and agriculture. Mutambi ward had a population of 3,944 and a total of 803 households (CSO 2002). The study villages had 210 households.

Zungwi vlei was converted to broad-ridge and broad-furrow in late 1998 and the work was finished in 2001. Fifty-four members joined the vlei scheme in 2001 and paid fees. They assisted with tilling the ridges and furrows. At the time of the study, Zungwi vlei had 42 members of which 28 were men and 14 women. Thirty-five of the members were married, six were widows and one was a widower. In principle, men and women did the same work and all members had equal rights including a right to vote and to speak one's views. Out of the 42 members 17 were from headman Musibandi and the rest were from headman Mwedzi's area. A seven-member committee largely drawn from headmen Mwedzi's area managed the scheme. The cooperative did not have a written constitution but instead used a verbal one. Since its inception the vlei scheme had two committees and three leaders, a sign of disagreements and unsatisfied scheme members. 


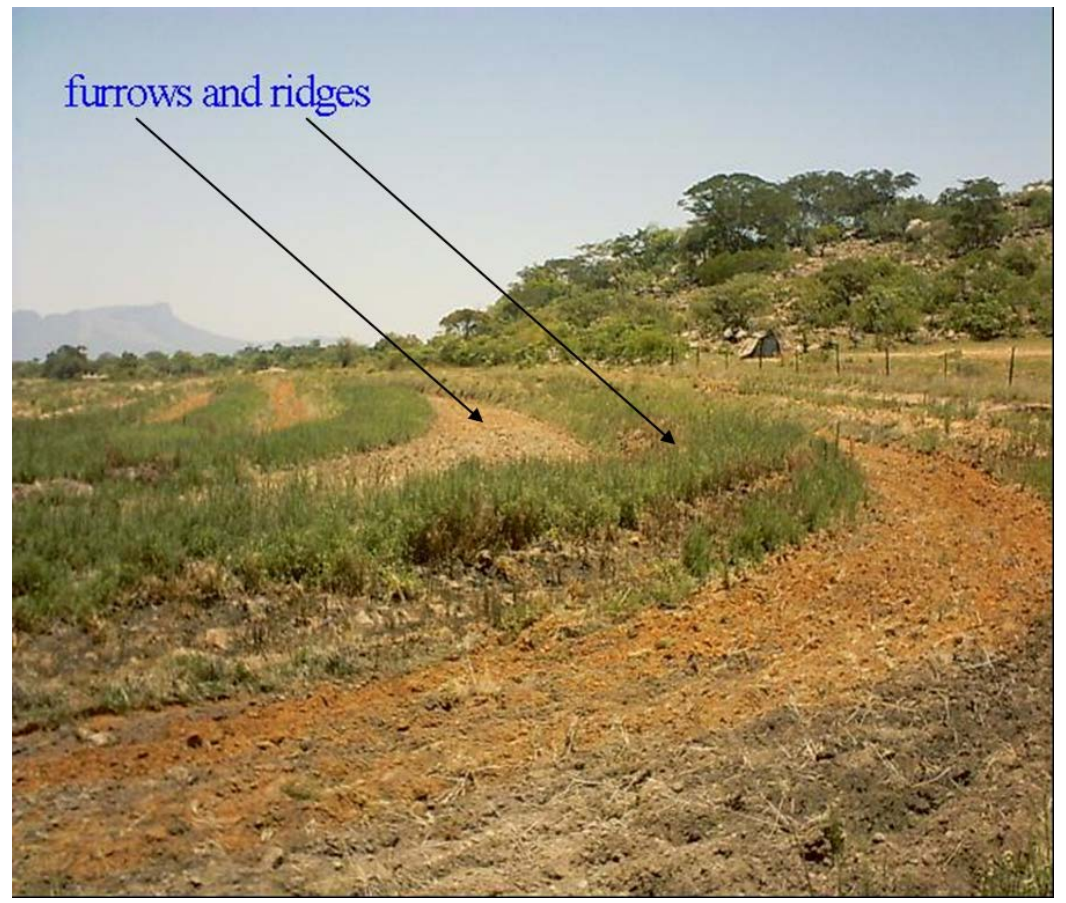

Figure 2: Broad-ridge and broad-furrow tillage technology. Source: Mbereko 2008.

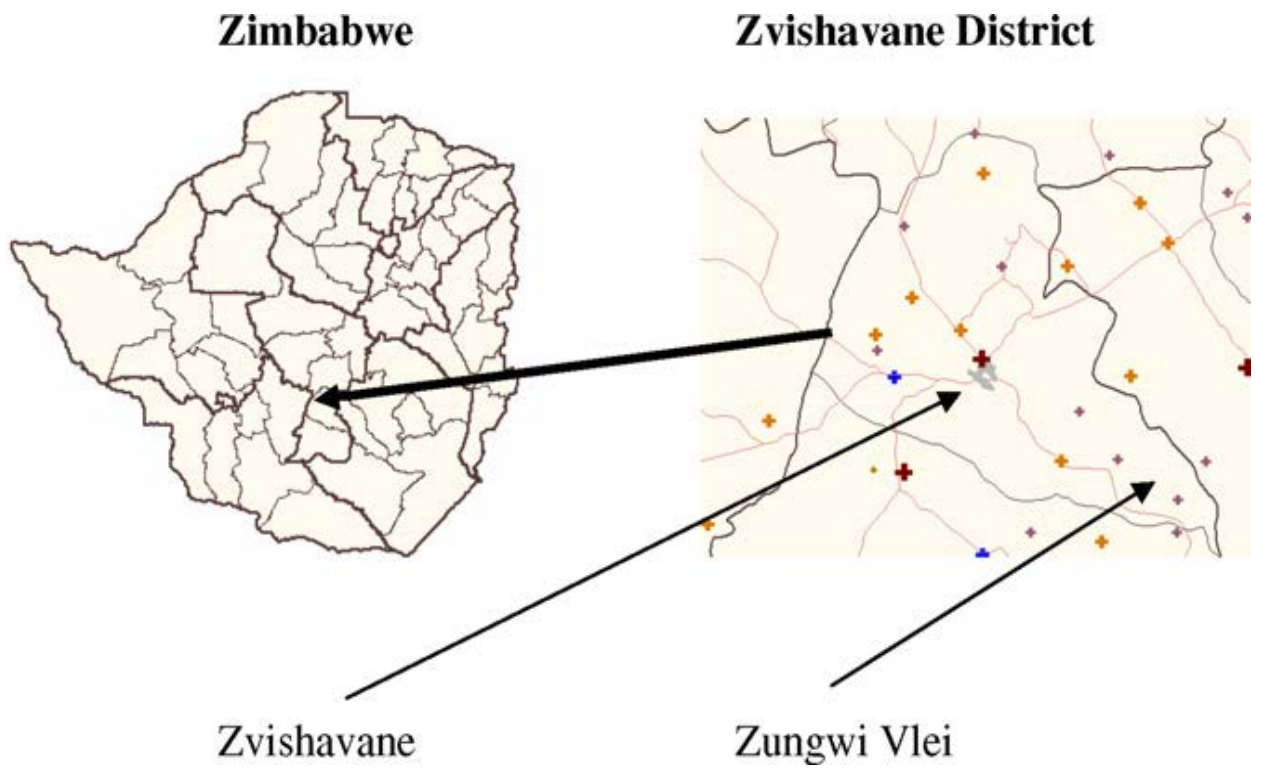

Figure 3: Map of Zimbabwe showing the study district and the position of Zungwi vlei.

\section{Methods}

Field research was conducted in Mazvihwa between 2005 and 2008, although further research in the area has not been possible. Households under headmen Mwedzi and Musibandi were selected as the target 
population, and spanning the five traditional authorities in Mazvihwa. These two areas were selected because scheme members and dispossessed people resided in both, and the vlei is on the boundary. We considered people who eat from the same pot daily as a household. The study population included traditional leaders, traditional spiritual leaders, a councillor, displaced farmers, and scheme members and non-members from Musibandi and Mwedzi. Structured and non-structured interviews were used to collect data on power dynamics before and after the inception of the technology, the form and underlying causes of conflicts, the reactions of the conflicting parties, and peoples' perceptions. In-depth interviews were held with key informants who were purposively sampled, to speak with people with the required information.

All of the vlei scheme members participated in a questionnaire survey, as well as 42 out of 213 nonmember households. Systematic sampling or every fifth household was used due to unreliable village registers. $^{2}$ The questionnaires were used to collect socio-demographic information, individual perceptions on the outcomes of the technology, and knowledge and impacts of conflicts. Eight focus group discussions (FGDs) were conducted with non-scheme members, ex-vlei farmers and scheme members. Their purpose was to triangulate the data from interviews and questionnaires and to obtain group perceptions, positions and plans. The first author also attended community meetings and activities.

\section{Results and discussion}

\section{Conflicts prior to the introduction of broad-ridge and broad-furrow technology}

The water and other natural resources of Zungwi vlei, unless in private fields, were formerly held as common property with open access (Mbereko et al. 2007). But the fields themselves were owned and controlled by individuals, essentially operating as custodians, many on the fringes of the vlei. Farming increased from the 1970s under the Mambeu family (Mbereko 2008). Trend analysis with the community showed conflicts over access and use increasing gradually before its transformation into a broad-ridge and broad-furrow irrigation landscape in 1999 (Figure 4). Non-scheme members identified conflicts at an earlier period than scheme members. For both groups, these conflicts were highest after the scheme started, from 2000 onwards. Most of the 76 survey respondents (86 \%) said there were no conflicts before the inception of the broad-ridge and broad-furrow technology, while others did identify traditional conflicts. Focus Group Discussion (FGD) narratives indicate that there were increasing resource pressures over time. In one FGD it was indicated that Zungwi vlei was seen as a lifeline for people and livestock during drought periods, since it never dried. FGD participants indicated that since the 1990s the area had experienced more frequent droughts than before, and this increases demand for vleis (Mbereko et al. 2007). Drought and pressure on resources intensified the contestations over Zungwi vlei by resource users, as observed elsewhere in Africa (Ashton 2002; Postel 2000; Scoones and Cousins 1994; Woodhouse et al. 2000).

The community managed the conflicts that emanated around Zungwi vleis using traditional institutions. Every village has a traditional court presided by the traditional leadership. The court sits periodically to resolve non-criminal cases like field disputes, crop destruction by livestock and customary issues in the vlei. Scoones and Cousins $(1989,1994)$ study in the same district identified similar conflicts; over increasingly scarce resources and the issue of ownership and control over the vleis. Prior to the initiation of the furrows, there was more prospect of conflicts being controlled by traditional institutions, which also mediates spiritual powers in the vleis. Since Mwedzi and the Musibandi people were from the same lineage, access to Zungwi vlei was not mutually exclusive, despite some shifting boundaries over time.

The Zungwi vlei had always been contentious because of its location on the boundary between two chieftainships. The boundary issues involving five headmen ${ }^{3}$ has been controversial and the state had to intervene on occasion. But it took advantage of the boundary conflicts to award and punish headmens' political support and cooperation. The boundary problem was indicated as one of the major issues in the Zungwi vlei conflict before the transformation of the vlei (See Box 1).

\footnotetext{
${ }^{2}$ The definitions of households in rural Zimbabwe are problematic since they can be altered depending on perceived benefits. For example, households can increase in size if NGO benefits are available, but decrease for the payment of village taxes.

${ }^{3}$ Ngowa dynasty included Mazvihwa, and the present headmen are descendants of Mazvihwa's sons (Mbereko 2008).
} 


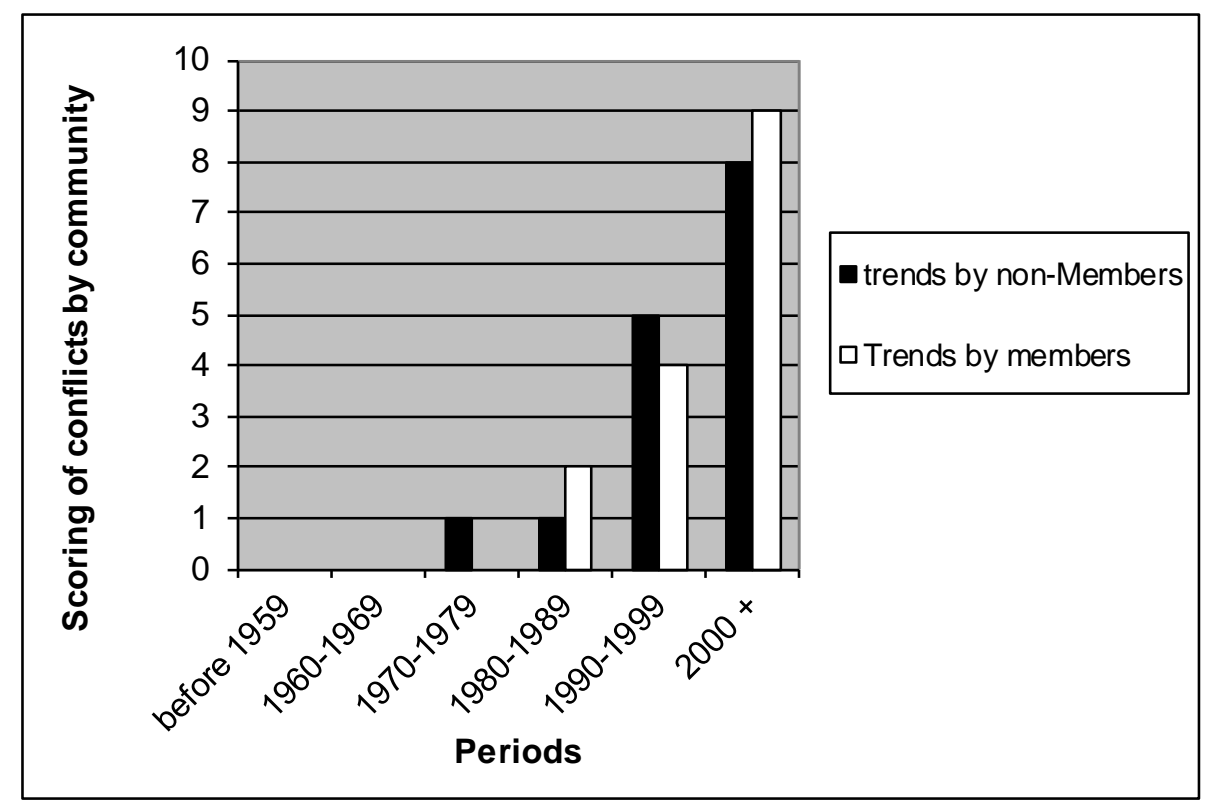

Figure 4: Scores awarded by scheme members and non-members to show levels of conflicts at different periods over time. Source: Mbereko 2008.

The reigning chief Mazvihwa passed away. In the succession dispute, territorial trade-offs were made by
the headmen as the competing candidates rewarded land in order to secure support for their aspirations
to occupy the throne. This brought the Zungwi vlei area into the wider political dispute. In the colonial
period (actual dates could not be established) people from Musibandi and few people from Mwedzi area
had fields on the vlei fringes. In order to exclude the people from Mwedzi the border was pushed
westwards, placing the Zungwi vlei entirely under headmen Musibandi. A District Administrator identified
as Mr. White came to settle the boundary issue of Musimbandi and Mwedzi areas. It is widely held that
the Traditional leaders appealed and paid bribes to their subjects who use to work for the colonial
government. The locals who worked in the D.A's office manipulated boundaries and influenced Mr.
White's judgement, and he gave full control of the vlei to headman Musibandi. Farmers from Mwedzi
villages were moved out and allocated fields elsewhere. In retaliation, Headman Mwedzi expelled
Musibandi's subjects who had fields in Mwedzi area, relocating them back to Musibandi. Some
respondents said the conflict had been resolved subsequently, following intervention by the chief and the
state. The Musibandi chief allowed free access to the water resource and the grazing area but restricted
access to sections of the vlei allocated for fields for the benefits of Musibande subjects only.

Box 1: The border dispute between headmen Mwedzi and Msibandi.

\section{Inception of the broad-ridge and broad furrow tillage system}

This section presents the findings on the beginnings of the broad-ridge and broad-furrow system, which was unilaterally implemented without the participation of the community. The exclusion of people who did not support this transformation of the Zungwi vlei began with access to information. There was disagreement among local people as to who came up with the idea of implementing the technology in Mutambi ward; $41 \%$ of the 72 respondents said it was the agricultural Research and Extension Services (AREX), 21\% said they did not know how the project came about, 18\% said it was the Smallholder Dry Area Resources Management Project (SDAMP), 14\% said the political leadership, and 6\% pinpointed traditional leadership. It was established in interviews with traditional and local government officials that it was 
SDAMP that appealed to councillors and chiefs at a council meeting to identify development projects, and they were the agency that sought to implement the tillage system in this particular location.

Mutambi ward community members learnt of the scheme at different occasions and from varied sources, as shown in Figure 5. The majority of the vlei members learnt of the scheme in the late 1990s from AREX officers, while the majority of non-members heard through the councillor and the traditional leadership. Thirty two percent (32\%) of scheme members learnt of the scheme at an important meeting held at the vlei. In-depth interviews with ex-vlei farmers and local leadership had referred to this meeting as the last before construction of the ridges and furrows started in 1999. The purpose of the meeting was to recruit scheme members and the decision to develop Zungwi vlei had already been made. One of the displaced farmers said:

I did not go for that meeting because they had decided to develop our fields in an earlier meeting held at Rambotemwa. Not everyone was invited for the earlier meeting except those who support them [councillor]. Today they invite everyone because the DA, researchers and government officials are attending the meeting. (Interview 7, 06/01/2006)

This demonstrates that the consultation meetings were selective in who attended, and this resulted in resentment about the meeting and further on, to the scheme itself. The lack of adequate consultation with the community influenced the active resistance to the transformation of Zungwi vlei.

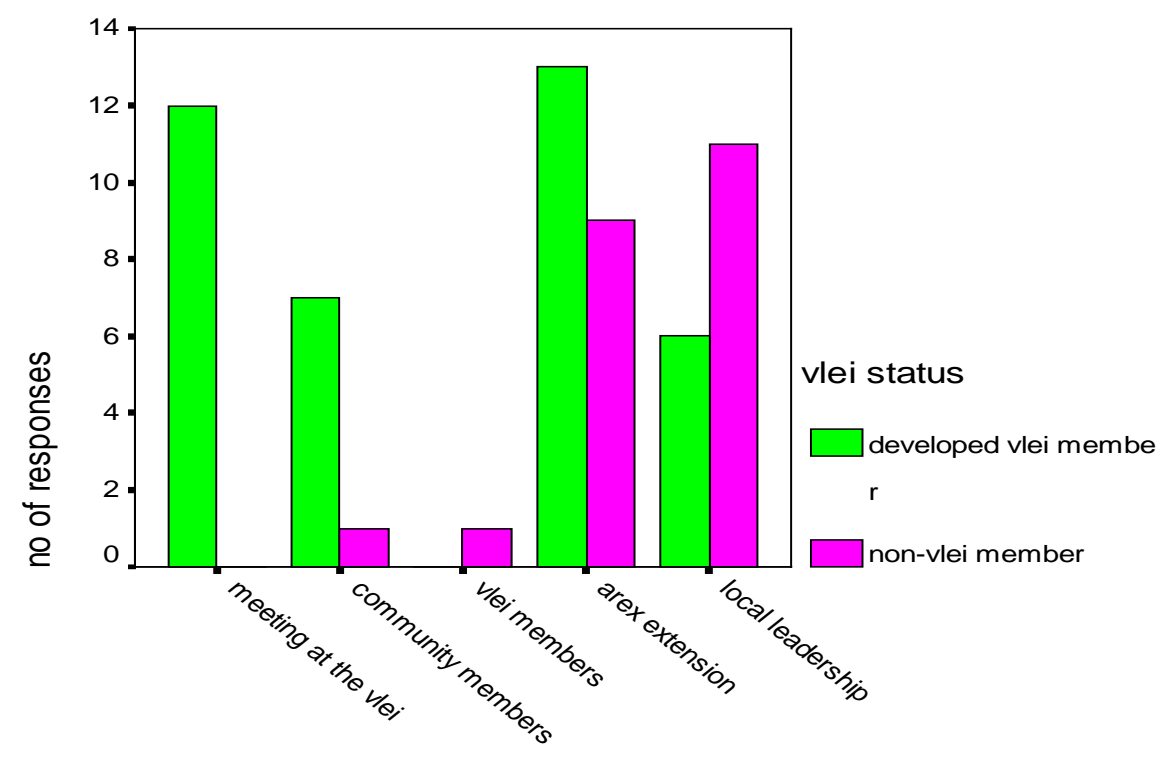

Figure 5: Sources of information about the inception of Broad-ridge and broad- furrow Technology in Mutambi ward by vlei status. Source: Mbereko 2008.

There were allegations that selection of Zungwi vlei for the scheme was influenced by political figures, including the councillor. All interviewees agree that at the meeting with SDAMP, community representatives were first asked to select development projects. People from Virimayi village argued for heifer and piggery projects, since vegetation in Zungwi vlei was recommended as good fodder for pigs and dairy cattle by the AREX officer (FGD 6, 10/11/2006). The Ziruvi community prioritised development of Ziruvi vlei using the broad-ridge and broad-furrow tillage system. When the two proposals were submitted to SDAMP for funding, the donor was in favour of the tillage system. Events from this stage demonstrate very low feedback to the community until the implementation stage. One ex-Zungwi vlei beneficiary said, "I only 
heard that a group of people had been taken to train in agriculture, little did we know they were being prepared to take over our fields" (Interview 5 11/5/2006). The surveyors and AREX officials identified three suitable sites in the region, which were Ziruvi vlei, November Vlei and Zungwi vlei.

The ex-vlei members assert that the political leaders pushed for the scheme to be located closer to their own village, depriving the Ziruvi villagers who wanted the scheme in their area. The sitting councillor, also the head of the Ward Development Committee, was from Mwedzi. In order to make political mileage by attracting development projects, he influenced the location of the vlei scheme towards Zungwi, closer to his village and his political stronghold. So, a project prioritised by Ziruvi people ended up being implemented on the Zungwi vlei. The councillor presided over the selection of the new scheme members, and this was received with mixed feelings. His critics blamed his selection of loyalists and more people from Mwedzi, as a way of fighting the boundary dispute that dated right back to the colonial era.

SDAMP funded a study visit to another vlei, for the new scheme members. Twenty-one people were selected by the councillor with the assistance of the village development committee (VIDCO) to go on a factfinding trip to Shurugwi and Mfiri vleis, already under broad-ridge and broad-furrow cultivation (Interview 12, 17/05/2007). Farmers who already had fields in the vlei were omitted from the exchange visit, and from other planning meetings and events. One of the traditional leaders who went on the trip commented that "In Shurugwi the scheme did not cause as much conflicts as at Zungwi because the vlei was used as pasture and not cultivated" (Interview 9, 27/04/2006). If the Shurugwi vlei was used for pasture it explains the low level of contest there over water rights, since pasture land is common property and no one in particular claims either ownership or usufruct rights. But Zungwi was different; it had farmers, and a history of disputed access and political control. The technocrats behind its development failed to consider the issue of water rights as a key difference.

The transformation and dispossession of other potential beneficiaries from accessing the Zungwi vlei involved a conjunction of actors. We know that politicians can use NGOs as a vehicle to enforce their legitimacy and to gain votes (Biehl 2011; Bryant and Bailey 1997). The Zungwi case demonstrates how an NGO, the state and scientists form partnerships despite their different interests, and cooperate to reshape the livelihoods of local people. Political ecologists argue that such interventions serve the interests and concerns of international institutions and powerful members of society, and tend to overshadow the interests of recipients. This results in interventions that reinforce inequalities in society (Biehl 2011).

\section{Post broad-ridge and broad-furrow technology conflicts}

Amongst the vlei scheme members, internal conflicts soon emerged. There were accusations of laziness, absenteeism, nepotism, and embezzlement of funds, revealed in the focus group discussions. Most of the respondents highlighted that sharing of ridges and furrows had been a major cause of conflict. Two or three members were given one ridge and furrow depending on the size. A number of the members were disgruntled since they were allocated infertile sections that were relatively less fertile and drier, while other got fertile fields but too wet (waterlogged for a greater part of the season). The scheme members were given rice seed to plough, but the crop did not do that well. In an focus group discussion they attributed this to some furrows being drier and poor soil quality than others. Some farmers reacted by neglecting their fields. An AREX officer has been present and presided over the reallocation process. Hence she was also blamed for causing the conflicts in the vlei. AREX officer and vlei committee were blamed for causing crop failures in the vlei by advising on the adoption of tillage practices that did not work. Thus, those with access to productive land were advantaged over those with drier fields.

As a result of these contests, a form of privatization eventually occurred, with the members allocating each other specific ridges and furrows. This marked the end of the Zungwi vlei scheme as a cooperative, and everyone then ploughed and managed their individual plots - but only the former scheme members were able to assert rights to be part of this gradual drift into privatization.

Interviews, focus groups and trend analysis indicated the presence of what the community described as "serious conflicts." Community respondents used strong language such as kurwisana and makakatanwa (fighting and strong disagreements respectively) to define the conflicting relations that existed. Implementation of broad-ridge and broad furrow technology had resulted in eight farmers losing their fields 
to the scheme members, plus, the wider community losing pasture and water sources. The ex-vlei farmers (those who lost their fields) had invested in their land by applying clay from anthills to improve soil fertility. One of the ex-vlei members had dug fishponds (approximately 10x10x5 meters in size) and was practicing aquaculture (FGI 3, 28/10/2006). The displaced farmers used the traditional dead-end furrow system to control and manage water for agricultural purposes. Some had orchards growing mangoes, guava, oranges, paw-paw and lemons. All interviews and FGI accounts relate that fruit trees, maize, sugar cane and other crops belonging to ex-vlei farmers were mowed down by earthmovers. Interviews with displaced farmers revealed that they were angry because they were displaced by scheme members and their livelihoods were dependent on the wetland vlei fields.

The displaced farmers had demanded compensation before construction commenced. The District Administrator (D.A.) and local leaders promised the displaced farmers upland fields as compensation, but the promise was not honoured. There was no written agreement and timeframe offered for the compensation of losses. Interviews with the councillor revealed that traditional leaders were tasked with allocating alternative fields for the displaced farmers. The local kraal head expected council and the chief to give them alternative fields. Two of the displaced farmers cultivated in their homestead backyards. One had a rented field. Other dispossessed farmers sought alternative sources of livelihood like gold panning and fishing in Runde River.

Yields from the vlei scheme declined after several seasons. One ex-beneficiary claimed to have harvested 1 tonne of wheat and 3.5 tonnes of maize in 1998, compared to the 1.5 tonnes of maize and 0.279 tonne of wheat harvested in the scheme in the 2003/4 season. The low yields from the scheme pained and angered displaced farmers and other community members who argue that the technique was not as productive as the previous ones they traditionally used (FGI, 4, 04/11/2006). In a questionnaire survey $72 \%$ of 64 responses highlighted that the vlei was properly utilized before the scheme while only $28 \%$ said that the vlei was well utilized by the scheme members. Those who supported the current vlei farmers argued that the current tillage system offered two or three crops per year in the vlei, which was not the case with traditional farming technology.

Some of the ex-vlei users and prospective scheme members were at conflict with the scheme members for denying them access. The majority (98\%) of 68 respondents said the vlei members refused to admit new members into the scheme. Half of them highlighted exorbitant joining fees as the major way used to keep newcomers out. In 2002, members demanded a joining fee of ZW\$10 (equivalent to US\$3). Some $36 \%$ of the respondents $(n=62)$ said that the vlei scheme was full, while $14 \%$ said new members were not wanted. Scheme members openly indicated this because they felt they had done too much work to be compensated by a joining fee of any amount. They also pointed out that they had given prospective members enough time to join in the past, and that the grace period had expired.

The surrounding community formerly derived numerous benefits from resources provided by Zungwi vlei, but they lost access after implementation of the new tillage system. Only 42 households had land and were cultivating on the furrows at the time of the study in the late 2000s. A community member indicated during a focus group that SDAMP and AREX did not tell them that they were going to fence the vlei and allocate land within, but they indicated only that they would 'take' the vlei (to the local people this meant using the waterway at the valley bottom). Livestock grazing has always been a competing use of the vlei but that became impossible. To discredit the scheme a kraal head, who was opposed to it, said "The scheme is supported by those without cattle." Coincidentally some of the vlei farmers and members had no cattle, and hence it was thought that they were insensitive to the needs of livestock herders. It was observed that some farmers graze their herds in the vlei on the edges of the scheme's fence. There were reports of cattle and their owners destroying the fence. In one focus group, non-Vlei members were blamed for letting their livestock inside the fenced area, although it was also highlighted that some vlei members also grazed their own livestock in or close to the scheme during a drought year.

Some traditional leaders indicated that the custodians of tradition opposed the tillage scheme, because the vlei is sacred and should not be fenced. Furthermore it was alleged that the ridges disturbed the road of mhondoro (the guardian of the lion spirits) to the Zungwi Mountain, which is the burial place of Chief Mazhihwa's family (Mbereko 2008: 129). Interview respondents and focus groups did not agree on whether the vlei was sacred or not. The elderly members of the community asserted this, especially in relation to a well - named Tsime ravachikamhi well, the nickname of Mafenya's wife whose field bordered it. 
Traditionalists and other community members expressed fears that the water in the sacred well would be affected by disobedience to customary rules, the application of fertilizers and the blocking of free water movement by the ridges and dam walls, and in 2005 it dried up. Vlei members and Christian converts believed that it was as a result of the drought spell. The descendants of Chikamhe had converted to Christianity, and hence they shared this view. The traditionalists and ex-vlei members believed that the ridges and the fence had caused the well to dry. They argued that the well never dried up during the droughts of 1981/2 or 1991/2 which were more severe than the 2004/5 dry period (Mbereko et al. 2007). They advocated for the scheme to be destroyed and to restore the vlei to its previous state.

This was unresolved, but in addition, the vlei members complained that fields upstream of their own captured water that the scheme was supposed to benefit from. At the same time people downstream of the vlei scheme claimed that a dam blocked water meant for their use. All respondents agreed that the flow had been reduced downstream. The community held the scheme responsible for this. According to vlei members, farmers downstream used the issue of the sacred well as an excuse for accessing the water for their fields and gardens. Downstream farmers claimed that the dam affected both water level and quality of the communal well. Other studies have demonstrated that changes in water control and ownership result in conflicts between the upstream and downstream users due to changes in formal or informal water rights (Mehta, Veldwisch and Franco 2012). Other studies allude to upstream-downstream conflicts over downstream impacts, e.g. pollution, reduced water quality and uncertain flow regimes (Goutbesville 2008; Savenije and Van der Zaag 2008). This study notes changing access rights as the major issue of conflict, and the hydrological status of the vlei was used to justify the attack on the scheme.

There were also conflicts between traditional leadership and the local government. The vlei scheme members indicated that the vlei resources belonged to the chief, and the project was under the jurisdiction of the councillor. Interviews with traditional leadership revealed their dissatisfaction; they, not the councillor, should be the arbiter of the scheme. A sub-chief said "Whenever vlei members have problems amongst themselves they refer their issues to the councillor to intervene and resolve their problems." While the councillor at the time did consult traditional leadership, fears were expressed this may not continue with a change in leadership. The traditional leadership certainly distanced themselves from the failures of the scheme members, and blamed the council. One of the sub-chiefs threatened to have the broad-ridge and broad-furrow destroyed and to reinstate the previous farmers, if the scheme became unproductive.

The broad-ridge and broad furrow technology brought about obvious contradictions within the Mazvihwa communal area. Typically, one section of the population was empowered while under-developing another. The tillage scheme redefined relations amongst community members and other external institutions through property and access. The Zungwi vlei scheme members were hated and despised by those who had lost their access rights. The politicians and extension workers changed overnight from opposing utilisation of the vlei to supporting it. Those who did not value their perspective were excluded and pushed to the periphery.The ex-beneficiaries derided the lack of compensation offered to them, hegemonic control, and the new focus on productivity (not delivered). Following Linebaugh (2009) the labor of the usurped farmers was transferred, like a commodity, to the new scheme participants, who continued to produce similar crops for the market. Their landesque investments in a sense had been transferred to another group of people.

Ultimately, the project, and the new cultivation technology it introduced, lacked community legitimacy. The broad-ridge and broad-furrow system, handed to the people of the vlei, generated a subculture of resistance. Makumbe (1996) argues that such projects can collapse as soon as they are handed over to the community to run and manage. The views and aspirations of the elite are not necessarily the same as those of farmers. Farmers resist what they do not want. This explanation applies to the Zungwi conflict in particular, but the internal conflicts around the scheme have more complex origins.

\section{Conclusion}

The issue cutting across all the forms of conflicts presented above is the attempts by dispossessed farmers and community to resist the privatisation of Zungwi vlei for the benefit of scheme members, who also wielded some political and economic power over the former through changing access rules (Mbereko et al. 2007). The struggle for control over resources is often centred on those that are the most valuable for 
livelihoods (Scoones and Cousins 1994). Control of Zungwi vlei was a key issue even before the development of the vlei its development using the broad-ridge and broad-furrow technology. Control also meant having the power to exclude other competing users, hence contestation over the vlei at household and community levels. Household level struggles were always about insuring access to soil, water, grazing and timber within the vlei. Community level contestations pitted headman versus headman, with politicians and funders playing out their interests in the vlei.

Marxist scholars suggest the combination of new scientific knowledge systems with commercial interests will result in conflict, if social and ecological changes is rapid. The case demonstrates some of the contradictions. Traditional knowledge, expressed through multiple and overlapping uses of the vlei, was rejected. And yet, production after the tillage system was introduced and the land was effectively privatized, was not as high. According to Wallis (2006) productivity is not always the real goal for commercially driven agricultural innovation; the goal can be to replace independent community-based agriculture with a form of production that maximises dependence on commercial inputs. But in this case, the dependence was more on local elites than inputs - for technical advice, decision-making, and conflict resolution. This was unsustainable since external institutions that were involved in the inception phase withdrew their support when the scheme was completed. To take a Marxist theorization further, this case demonstrate accumulation by the Zungwi vlei scheme members, at the expense of the community who were dispossessed of their access rights to a common pool natural resource. The scheme members were backed by politicians and an NGO. For ZANU PF, the national political party, it was killing two birds with one stone; political mileage was made while promoting development. Conversion of common property to private property promotes market interests but also social inequalities through competition for scarce resources, reducing development benefits. Those who lose access rights contest in different ways (Hall et al. 2011; Scott 1985). In the case of Zungwi vlei the dispossessed social actors resisted the scheme actively (using violence) and latently (sabotage).

The biggest failure of the scheme was the implementers' failure to take into account water and land rights contestations. Scholars have theorised that such contestations over water resources are informed by material, discursive, administrative and political power as they enable water reallocation and tenure changes (Mehta et al. 2012). More so, both the community and the recruited members did not co-evolve with the technology, hence the need to have allowed adoption and incorporation into local culture and agricultural practices. Political ecologists argue that communities have power to modify and interact with modern scientific knowledge systems. In the case study presented here, the Zungwi community were only made users of the cultivation techniques and furrows, and when external support was withdrawn the project showed signs of natural death.

The United Nations argues that there are three ways of viewing popular participation in development; mass contribution to the development effort, mass sharing of benefits and mass decision-making (Makumbe 1996). The broad-ridge and broad-furrow technology was external to this community. The problem was that the decision to commence the scheme had already been made by politicians, other local elites, and researchers. SDAMP had the capital and supported the broad-ridge and broad-furrow tillage system. The politicians and other local elite were influenced to act according to SDAMP's interests and appended their interests. Thus, the local access dynamics and control struggles over the Zungwi vlei were ignored. These may have been trivialised because donor funds have strict time lines that have to be fulfilled. Hence structural problems are more to blame than local actors. the sudden change in key resources that support livelihoods created contestations that would have been worked out over much longer timeframes. Wallis (2006) notes that the issue rests not with any particular inventions, but rather in the organisation of society in such a way that technological choices are not made on the basis of marketability and profit potential, but rather on the basis of compatibility with the overall needs of humanity and the natural world.

The contribution to political ecology is to demonstrate the reaction to innovations that negatively affect access to key resources, and their embeddedness within structures of inequality and conflict. For scientists, broad-ridge and broad-furrow technology was novel (Mharapara 1995), even though there were discontinuities and serious contradictions around Zungwi vlei. Despite its potential, in this case the technology was rendered useless by the conflicts over access, use and management. Privatising the common pool resource and limiting access to the vlei were largely to blame. This altered the values, interests, information, knowledge and power of the community. Existing conflicts were magnified. 


\section{Bibliography}

Abdulai, A., and W.E. Huffman. 2005. The diffusion of new agricultural technologies: the case of crossbredcow technology in Tanzania. American Journal of Agricultural Economics 87(3): 645-659.

Adesina, A.A. and J. Baidu-Forson. 1995. Farmers' perceptions and adoption of new agricultural technology: evidence from analysis in Burkina Faso and Guinea, West Africa. Agricultural Economics 13(1): 1-9.

Appleton, C.C. and H. Madsen. 2012. Human schistosomiasis in wetlands in southern Africa. Wetlands Ecology and Management 20(3): 253-269.

Ashton, P.J. 2002. Avoiding conflicts over Africa's water resources. Ambio 31 (3): 236-242.

Ariza-Montobbio, P., Lele, S., Kallis, G., and J. Martinez-Alier. 2010. The political ecology of Jatropha plantations for biodiesel in Tamil Nadu, India. The Journal of Peasant Studies 37 (4): 875-897.

Balasubramanian, V., M. Sie., R.J. Hijmans and K. Otsuka. 2007. Increasing rice production in sub-Saharan Africa: challenges and opportunities. Advances in Agronomy 94: 55-133.

Berger, G. 2005. Modernisation and Africa's emerging engagement with the information society. AfroGEEKS, University of California, Santa Barbara.

Bhalla, A., Davies, R., Chitiga-Mabugu, M. and Mabugu, R. 1999. Globalization and sustainable human development: progress and challenges for Zimbabwe. UNCTAD/UNDP. http://unctad.org/en/Docs/poedmm128.en.pdf [Accessed on 20/11/2012].

Bolding, A. 2004. A study of sociotechnical intervention models and practices of water use in smallholder agriculture, Nyanyadzi catchment, Zimbabwe. PhD thesis, Wageningen University.

Brett, E.A. 2005. From corporatism to liberalization in Zimbabwe: economic policy regimes and political crisis, 1980-97. International Political Science Review 26(1): 91-106.

Bryant, R.L. 1998. Power, knowledge and political ecology in the third world: a review. Progress in Physical Geography 22(1): 79-94.

Central Statistics Office. (CSO) 2002. Census 2002 report. Harare: CSO.

Ciccantell, P. 2001. NAFTA and the reconstruction of US hegemony: the raw materials foundations of economic competitiveness. Canadian Journal of Sociology 26 (1): 47-65.

Clifford, N.J. 2009.Globalization: a physical geography perspective. Progress in Physical Geography 33(1): 5-16.

Frank, D. 2007. Consuming landscapes: towards a political ecology of resource appropriation. PhD thesis. Griffith University.

Hall D., P. Hirsch and T. Murray Li. 2011. Powers of exclusion: land dilemmas in Southeast Asia. Honolulu: University of Hawai'i Press.

Harvey, D. 2003. The new imperialism. Oxford and New York: Oxford University Press.

Heynen, N. and Robbins, P. 2005. The neo-liberalization of nature: governance, privatization, enclosure and valuation. Capitalism Nature Socialism 16(1): 5-8.

Hoffman, A.J. 2001. Linking organisational and field level analyses: the diffusion of corporate environmental practice. Organisational and Environment 14(2): 133-156.

Juma, C., K. Fang., D. Honca. J. Huete-Perez., V. Konde and S.H. Lee-Juma. 2001. Global governance of technology: meeting the needs of developing countries. International Journal of Technology Management 22(7/8): $629-655$.

King, B. 2010. Political ecologies of health. Progress in Human Geography 34(1): 38-55.

Kwansah-Aidoo, A., and L. Obijiofor. 2006. Patterns of internet use among university students in Ghana. In Ayadi, K.O. (ed.). African development: what role for business? Proceedings of the International Academy of African Business and Development Conference, 23-27 May 2006, vol. 7. Accra: Ghana Institute of Management and Public Administration. Pp. 359-365.

Linebaugh, P. 2009. Taking liberties: who? Whom? Capitalism Socialism Nature 20(4) 103-111.

MacKendrick, N.A. and D.J. Davidson. 2007. State capital relations in voluntary environmental improvement. Current Sociology 55(5): 674-695. 
Makadho, J.M. 1996. Potential effects of climate change on corn production in Zimbabwe. Climate Research 6(2):147-151.

Makumbe, J. M. 1996. Participatory development: the case of Zimbabwe. Harare: University of Zimbabwe Publications.

Matiza, T. 1992. The utilisation and status of dambos in southern Africa: a Zimbabwe case study. In Matiza, T. and H.N. Chabwela (eds.). Wetlands conservation conference for Southern Africa. Proceedings of the SADC Wetlands conference. IUCN. Pp. 91-104.

Mbereko, A. 2008. Understanding socio-economic outcomes of technological innovations over access, use and management of natural resources in Zimbabwe: a case study of Zungwi vlei (Zvishavane district). MPhil, Centre for Applied Social Sciences (CASS). Harare: University of Zimbabwe.

Mbereko, A., M.J. Chimbari and B.B. Mukamuri. 2007. An analysis of institutions associated with wetlands use, access and management in communal areas of Zimbabwe: a case study of Zungwi vlei, Zvishavane. Journal of Physics and Chemistry of the Earth 32: 1291-1299.

Mbereko, A., Scott, D. and Kupika, O.L. (in press). First generation land reform in Zimbabwe: historical and institutional dynamics informing households' vulnerability in the Nyamakate Resettlement community. Journal of Sustainable Development in Africa.

Mehta, L., G.J. Veldwisch, and J. Franco. 2012. Introduction to the special issue: water grabbing? Focus on the (re) appropriation of finite water resources. Water Alternatives 5(2): 193-207.

Mharapara, I.M. 1995. A fundamental approach to dambo utilisation. In Owen, R. Verbeek K., Jackson J. and Steenhuis, T. (eds.). Proceedings for a workshop on Dambo farming in Zimbabwe: water management, cropping and soil potentials for smallholder farming in the wetlands. Conference Proceedings. Harare: UZ Publications. Pp. 1-8.

Mitsch, W.J. and J.G. Gosselink. 2007. Wetlands. $4^{\text {th }}$ Ed. New Jersey, USA: Wiley.

Moore, D.B. 1991. The ideological formation of the Zimbabwean ruling class. Journal of Southern African Studies 17(3): 472-495.

Moyo, S. 2001. The land occupations movement and democratisation: the contradictions of the neoliberal agenda in Zimbabwe. Millennium Journal of International Studies 30(2): 311-330.

Mukamuri, B. B. and T. Mavedzenge. 2000. Policies on the cultivation of vleis in Zimbabwe and local resistance to their enforcement. Managing Africa's Soils No. 14. London: IIED.

O'Connor, J. 1998. Natural causes: essays in ecological Marxism. New York: Guilford Press.

Peluso, N.L. 1992. Rich forests, poor people: resource control, and resistance in Java. University of California Press.

Postel, S. 2000. Entering an era of water scarcity: the challenges ahead. Ecological Applications 10(4): 941948.

Rattray, J.M., R.M.M. Cormack, and R.R. Staples. 1953. The vleis of Southern Rhodesia and their uses. Rhodesia Agricultural Journal 50:465-483.

Ribot, J.C. and Peluso, N.L. 2003. A theory of access. Rural Sociology 68(2): 153-181.

Savenije, H. H. G., and P. Van der Zaag. 2008. Integrated water resources management: concepts and issues. Physics and Chemistry of the Earth, Parts A/B/C 33(5): 290-297.

Scoones, I. and B.B. Cousins. 1989. A participatory model of agricultural research and extension: the case of vleis, trees and grazing schemes in the dry south of Zimbabwe. Zambezia XVI(i): 45-65.

Scoones, I. and B.B. Cousins. 1994. Struggle for control over wetland resources in Zimbabwe. Society and Natural Resources 7 (6): 579-594.

Scott, J. 1985. Weapons of the weak: everyday forms of peasant resistance. New Haven: Yale University Press.

Scott, J. 1990. Domination and the arts of resistance: hidden transcripts. New Haven: Yale University Press.

Sithole, B. B.1999. Use and access to dambo in communal lands in Zimbabwe: institutional considerations. $\mathrm{PhD}$ thesis, Centre for Applied Social Sciences (CASS). Harare: University of Zimbabwe. 
Soron, D. 2004. The cultural politics of Kyoto: lessons from the Canadian semi-periphery. Capitalism Nature Socialism 15(1): 43-66.

Thrupp, L. A. 1993. Political ecology of sustainable rural development: dynamics of social and natural resource degradation. In Allen, P. (ed.) Food for the future: conditions and contradictions of sustainability. London: John Wiley. Pp. 47-73.

Tripp, R. 2001. Agricultural technology policies for rural development. Development Policy Review 19(4): 479-489.

Wallis, V. 2006. Socialism and technology: a sectorial overview. Capitalism Nature Socialism 17 (2): 81-98.

Webersik, W. and C. Wilson. 2009. Achieving environmental sustainability and growth in Africa: the role of science, technology and innovation. Sustainable Development 17: 400-413.

Whitlow, J.R. 1990. Conservation status of wetlands in Zimbabwe: past and present. GeoJournal 20 (3): 191202.

Wilson, K.D. 1986. Aspects of the history of vleis cultivation in Southern Zimbabwe. Department of Land Management. Harare: University of Zimbabwe.

Woodhouse, P., H. Bernstein, and D. Hulme (eds.). 2000. African enclosures? Oxford: James Currey. 